\title{
Monitoring, Mentoring and Measuring Metrics, and Outcomes for Pancreatic Cancer
}

\author{
Avram m Cooperman ${ }^{1 *}$, Michael Wayne do $^{2}$, Justin Steele ${ }^{3}$ and Mazen iskandar ${ }^{4}$ \\ ${ }^{1}$ Boca Raton Community Hospital, Albert Einstein-Montefiore Medical Centre Boca Raton, USA \\ ${ }^{2}$ Beth Isreal Medical Center, USA \\ ${ }^{3}$ St. Vincent's Hospital Manhattan, USA
}

${ }^{4}$ Department of Surgery, The Mount Sinai Hospital, USA

Submission: April 30, 2018; Published: May 14, 2018

"Correspondence Address: Avram m Cooperman, Boca Raton Community Hospital, Albert Einstein-Montefiore Medical Centre Boca Raton, Florida, USA, Email: avram.cooperman@gmail.com

\section{Editorial}

It is the time of the year in the u.s.a. When the professional basketball season is determining its best team and next champion by a series of playoff games. During a 75 regular season schedule nearly every offensive and defensive metric on every player has been recorded and analyzed, including field goal and foul shooting percentages, assists, rebounds, blocked shots, and how various players fare against opponents. Individual weaknesses are exposed and exploited [1]. Depending on outcomes, renewal of coaches and players contracts hangs in the balance. Actual outcomes at the seasons end may be far different than pre or mid season projections. For certain, poor outcomes require a change in personnel, strategy or both.

\section{Surgery and its Timing}

That is not the case with pancreatic cancer where a long standing tradition and mantra champion's surgery as "the only chance of cure" for a disease whose 5 cure rate is dismal and unchanged at $5 \%$ for 40 years. The metrics of respectability rates, length of surgery and hospitalization, morbidity, and mortality rates and outcomes after treatment, including measures of lifestyle (diet and exercise) need be known. Long term cure of cap is very unusual if not rare. Regardless of treatment [2]. Surgery has the benefit of selection bias. Rather than being the only chance of cure, healthier patients with more favorable tumors were funneled to surgeons as radiation, and systemic chemotherapy options were limited. Only recently other local ablative measures, microwave, hifu (high intensity frequency ultrasound), and 'radiofrequency have been applied. They are local measures and will not influence long term outcomes.

Most importantly since metastases are evident within a year of resection in $80+\%$ of resected patients, surgery first is an illogical and ill conceived first therapy. A long overdue moratorium is needed. A few studies have indicated neoadjuvant therapy for $4-10$ mos has positive effects on the tumor, and if ineffective provides time to detect the more aggressive tumors in up to $40 \%$ of initially resectable tumors. Sparing an unnecessary pancreatic resection [3]. Actual 5 and 10 year survival has been significantly better than surgery first in 2 neoadjuvant studies $27 \%$ and $14 \%$ of 327 patients and $8 / 19$ patients.

\section{Length of Surgery}

There has never been a reported advantage or benefit from a lengthy pdr compared to the same operation done in much less time. A short operation implies less blood loss, and fewer intraoperative complications. When correlated with a shorter postoperative hospital stay, low readmission and low fistula rates and shorter convalescence. Why should mean operative time amongst experienced surgeons vary from $2 / 12$ to 8 or more hours. And not decrease with experience. We have no explanation but it could be beneficial for all to visit, observe and be open to modify their techniques [4].

\section{Laparoscopic Versus Open Surgery}

The issue of operating time will be extrapolated to laparo robotic pancreatic resections. A few surgeons skilled and experienced in both pancreatic and advanced laparoscopic surgery. Have reported impressive outcomes with operative times of 5-6 hours which approximates the mean times of many with open pdr's and lesions. This is a skill set those select individuals' posses. It would be wrong for established, experienced open surgeons to assume they will develop the needed skill set. They should assist their skilled laparoscopic counterparts to facilitate an accurate timely operation.. Advanced minimally invasive pancreatic operations are routine for a select few technical advances and modifications are just that and cannot alter the systemic nature of the disease.

\section{Mentors}

It has been perplexing that completion of residency or fellowship in June provides the rudiments for the next step of the 
learning curve. This takes several years, during which; technical skills. Judgment and knowing what not to do improve as modesty and self comfort develop. It takes years of surgical practice at a high volume center to become a sound skilled surgeon, this phase can be shortened and facilitated by an experienced surgeon whose practice will be assumed by a younger surgeon and who is involved in every step of decision making, our own observations are morbidity is less and introspection, intellectual honesty and open mindeness develop more quickly.

\section{Prevention}

Anything that would reduce the incidence of cap would be welcome. Prevention will be of little salvation for those with cap but might delay, or temper the presentation and course. The accumulating evidence incriminating a western diet as a causative factor in gastrointestinal cancer in 50-90\% of cases, including pancreatic cancer has not yet caught sufficient attention or adherents. Hopefully it will be a matter of time.

\section{Actual Not Actuarial Survival}

Projecting survival is not actual survival. Wishing for better and longer survival has not made it so. In an attempt to prove this, projected not actual survival statistics are published. When
Kaplan and meier introduced projected survival they suggested it be used when actual survival could not be determined. For aggressive malignancies with limited survival (i.e., pancreatic cancer) differences of 4-5x have been reported between actual and actuarial survival. Favoring of course actuarial survival. This is not only inaccurate but hides how poor survival really is with cap. By being open to changing treatment better outcomes might be achieved. As Einstein suggested, insanity was doing the same thing over and over again and expecting a different outcome". It is long past due we changed the metrics, lifestyle, approaches and outcomes for pancreatic cancer.

\section{References}

1. Cooperman AM, Bruckner H, Snady H, Hammerman H, Fader A, et al. (2018) Cancer of the Pancreas-Actual 5, 10, and 20+Year Survival: The Lucky and Fortunate Few. Surg Clin North Am 98(1): 73-85.

2. Cooperman AM, Iskandar ME, Wayne MG, Steele JG (2018) Prevention and Early Detection of Pancreatic Cancer. Surg Clin North Am 98(1): $1-12$.

3. Wolff RA (2018) Adjuvant or Neoadjuvant Therapy in the Treatment in Pancreatic Malignancies: Where Are We? Surg Clin North Am 98(1): 95-111.

4. Coppola A, Stauffer JA, Asbun HJ (2016) Laparoscopic pancreatoduodenectomy: current status and future directions. Updates Surg 68(3): 217-224.

This work is licensed under Creative Commons Attribution 4.0 License

DOI: 10.19080/CTOIJ.2018.10.555796

\section{Your next submission with Juniper Publishers will reach you the below assets}

- Quality Editorial service

- Swift Peer Review

- Reprints availability

- E-prints Service

- Manuscript Podcast for convenient understanding

- Global attainment for your research

- Manuscript accessibility in different formats ( Pdf, E-pub, Full Text, Audio)

- Unceasing customer service

Track the below URL for one-step submission https://juniperpublishers.com/online-submission.php 